\title{
FORMULASI JAGUNG HIBRIDA (Zea mays L.) DAN JAGUNG MANIS (Zea mays saccharata) PADA PEMBUATAN SUSU JAGUNG
}

\author{
Formulation Of Maize Maize (Zea Mays L.) And Sweet Maize (Zea Mays Saccharata) In \\ Making Maize Milk
}

\author{
Muh Arsyad dan Maryam Hulinggi \\ Email:arsyadmaner@gmail.com
}

\author{
Program Studi Teknologi Hasil Pertanian, Fakultas Pertanian, \\ Universitas Ichsan Gorontalo
}

\begin{abstract}
Abstrak
Tujuan penelitian ini yaitu untuk mengetahui pengaruh proporsi jagung hibrida dan jagung manis pada pembuatan susu jagung dan mengetahui tingkat penerimaan panelis terhadap susu jagung dengan formulasi jagung hibrida dan jagung manis. Penelitian ini meliputi 4 perlakuan dan 3 ulangan dengan menggunakan Rancangan Acak Lengkap (RAL). Formulasi jagung hibrida dan jagung manis yaitu 200g jagung hibrida dan $800 \mathrm{~g}$ jagung manis, $400 \mathrm{~g}$ jagung hibrida dan 600g jagung manis, $600 \mathrm{~g}$ jagung hibrida dan $400 \mathrm{~g}$ jagung manis, $800 \mathrm{~g}$ jagung hibrida dan $200 \mathrm{~g}$ jagung manis. Parameter yang diamati adalah kadar air, kadar gula, viskositas, dan uji organoleptik terhadap rasa, warna, aroma, dan kekentalan susu jagung. Hasil penelitian ini menunjukkan bahwa kadar air dan kadar gula susu semakin meningkat dengan bertambahnya formulasi jagung hibrida dan jagung manis pada susu jagung. Viskositas semakin menurun dengan bertambahnya formulasi jagung hibrida dan jagung manis. Uji kesukaan terhadap warna dan kekentalan diperoleh susu jagung yang lebih disukai pada perlakuan A1 dengan formulasi jagung hibrida $400 \mathrm{~g}$ dan jagung manis $600 \mathrm{~g}$, sedangkan tingkat kesukaan terhadap rasa dan aroma diperoleh susu jagung yang lebih disukai pada perlakuan A2 dengan formulasi jagung hibrida $600 \mathrm{~g}$ dan jagung manis $400 \mathrm{~g}$.
\end{abstract}

Kata kunci : susu jagung, jagung manis, jagung hibrida

\begin{abstract}
The purpose of this study is to determine the effect of the proportion of hybrid corn and sweet corn in the manufacture of corn milk and determine the level of panelist acceptance of corn milk with hybrid corn and sweet corn formulations. This study included 4 treatments and 3 replications using a completely randomized design (CRD). Formulations of hybrid corn and sweet corn are $200 \mathrm{~g}$ hybrid corn and $800 \mathrm{~g}$ sweet corn, $400 \mathrm{~g}$ hybrid corn and $600 \mathrm{~g}$ sweet corn, $600 \mathrm{~g}$ hybrid corn and $400 \mathrm{~g}$ sweet corn, $800 \mathrm{~g}$ hybrid corn and $200 \mathrm{~g}$ sweet corn. The parameters observed were water content, sugar content, viscosity, and organoleptic test on taste, color, aroma, and viscosity of corn milk. The results of this study indicate that the water content and milk sugar content are increasing with the increase in hybrid corn and sweet corn formulations in corn milk. Viscosity decreases with increasing formulation of hybrid corn and sweet corn. Preference test for color and viscosity obtained corn milk which is preferred in A1 treatment with $400 \mathrm{~g}$ hybrid corn formulation and $600 \mathrm{~g}$ sweet corn, while the preference level for taste and aroma is obtained for corn milk which is preferred in A2 treatment with $600 \mathrm{~g}$ hybrid corn formulation and $400 \mathrm{~g}$ sweet corn.
\end{abstract}

Keywords: corn milk, sweet corn, hybrid corn

\section{PENDAHULUAN}

Jagung merupakan salah satu tanaman pangan yang memiliki peranan strategis dan bernilai ekonomis serta mempunyai peluang untuk dikembangkan. Jagung sebagai sumber utama karbohidrat dan protein setelah beras, disamping itu jagung juga berperan sebagai bahan baku industri pangan, industri pakan, dan bahan bakar (Siregar,2009). 
Kabupaten Pohuwato merupakan salah satu daerah penghasil jagung dan setiap tahunnya mengalami peningkatan. Produksi jagung pada tahun 2011 sebesar 320.306,1 ton, pada tahun 2012 mencapai $339.509,95$ ton, pada tahun 2013 produksi jagung mencapai hingga 341.090,5 ton dan pada tahun 2014 mengalami peningkatan hingga 341.090,50 ton (Dinas Pertanian dan Ketahanan Pangan kabupaten Pohuwato, 2014).

Sebagian besar hasil produksi jagung di Pohuwato hanya dijual dalam bentuk segar yang biasanya diolah atau dikonsumsi sebagai jagung rebus, jagung bakar, milu siram, dan olahan kue basah. Sebagian besar jagung yang sudah tua diolah menjadi beras jagung, makanan ringan (marning jagung) dan sebagian besar dimanfaatkan untuk bahan pakan ternak. Tanaman jagung di Pohuwato belum diupayakan dan dikembangkan dengan baik, masih kurangnya diversifikasi tanaman jagung menjadi produk olahan yang berdaya jual tinggi dan bernilai ekonomis. Hal ini disebabkan karena belum tersebar dan berkembangnya informasi mengenai inovasi yang dapat menggugah masyarakat untuk memanfaatkan jagung sebagai bahan baku pangan.

Penganekaragaman produk olahan perlu dilakukan untuk meningkatkan nilai tambah dan pendapatan petani. Salah satu pemanfaatan jagung yang bisa dikembangkan adalah pembuatan susu jagung. Susu jagung dikenal pula dengan sebutan corn milk, minuman ini dapat memulihkan energi dalam waktu cepat dan menjaga kesehatan mata, hati, lambung usus serta diyakini sebagai minuman bebas kolesterol, juga dapat mengobati penyakit diabetes karena mengandung gula alami (Supriyanto, 2006).

Pemanfaatan jagung menjadi susu jagung memiliki banyak kelebihan jagung diantaranya adalah pengolahan jagung menjadi susu jagung ini tidak membutuhkan peralatan yang sangat canggih dan cara yang sangat rumit sehingga dapat dengan mudah diaplikasikan pada lingkungan masyarakat petani, khususnya masyarakat petani Kabupaten Pohuwato.Kelebihan susu jagung dibandingkan dengan susu sapi atau kedelai adalah bahan bakunya mudah didapat dengan harga tidak terlalu tinggi dan mengandung serat lebih banyak. Jagung tidak mengandung lactate intolerance (yang membuat susu bau amis). Pembuatan susu jagung dengan menggunakan formulasi jagung manis dan jagung hibrida belum banyak dimanfaatkan dan diolah oleh masyarakat sehingga perlu dilakukan penelitian untuk pengembangannya dalam rangka penganekaragaman produk olahan jagung. 


\section{METODOLOGI PENELITIAN}

Tempat Penelitian

Pelaksanaan penelitian dan uji organoleptik di laboratorium pertanian Universitas Ichsan Gorontalo dan Uji penelitiandilakukan di Laboratorium Teknologi Hasil Pertanian Politeknik Gorontalo.

\section{Alat dan Bahan}

Alat yang digunakan pada penelitian ini adalah blender, pisau, baskom, sendok pengaduk, kain saring, panci stenless steel, kompor, termometer air raksa, botol kemasan/cup plastik,cawan petri, refraktometer, timbangan digital, dan viskometer brookfield.

Bahan yang digunakan pada penelitian ini adalah jagung hibrida muda, jagung manis muda, gula pasir, air, garam, natrium benzoat..

\section{Prosedur Penelitian}

\section{Pembuatan Susu Jagung}

a. Mensortasi jagung muda agar terhindar dari ulat serta tidak tua dan kering

b. Mengupas dan memipil Jagung.

c. Menimbang jagung pipilan $(1 \mathrm{~kg})$

d. Menghaluskan Jagung pipilan menggunakan blender kemudian disaring menggunakan kain saring

e. Menambahkan gula 400 gr dan garam 20 gr kedalam filtrat yang dihasilkan kemudian diaduk sampai homogen f. Memanaskan filtrat pada suhu 70$80^{\circ} \mathrm{C}$ selama 15 menit

g. Mengemas susu jagung kedalam dalam botol kemasan plastik kaku dalam keadaan panas dan tutup sesegera mungkin untuk menghindari kontaminasi mikroba.

\section{Perlakuan Penelitan}

Perlakuan penelitian adalah formulasi jagung manis dengan jagung hibrida.Untuk masing-masing perlakuan dilakukan sebanyak 3 kali.

$A_{0}=200$ gr jagung hibrida +800 gr jagung manis

$A_{1}=400$ gr jagung hibrida +600 gr jagung manis

$A_{2}=600$ gr jagung hibrida+ 400 gr jagung manis

$\mathrm{A}_{3}=800$ gr jagung hibrida +200 gr jagung manis

\section{Parameter Pengamatan}

a. Kadar Gula

Analisa total gula dilakukan dengan menggunakan refraktometer. Prinsip kerja refraktometer adalah menyerap cahaya yang terdapat pada sampel. Prosedur kerja : sampel dihaluskan, kemudian diteteskan pada prisma. Refraktometer menghasilkan data total gula dalam satuan brix.

\section{b. Kadar Air}

Pengukuran kadar air sampel dilakukan dengan proses pengeringan. Prosedur kerja pengukuran kadar air 
adalah cawan kosong dan tutupnya dikeringkan dalam oven selama 15 menit; ditimbang dengan cepat kurang lebih 5 gr sampel yang sudah dihomogenkan dalam cawan; dimasukkan dalam cawan kemudian dimasukkan oven selama 3 jam; cawan didinginkan 3-5 menit. Setelah dingin bahan ditimbang kembali; bahan dikeringkan kembali dalam oven 30 menit sampai diperoleh berat yang tetap; bahan didingikan kemudian ditimbang sampai diperoleh berat yang tetap (Sudarmadji dkk., 1989). Dihitung kadar air dengan rumus:

$$
\% \text { kadar air }=\frac{\mathrm{BA}-\mathrm{Ba}}{\mathrm{BA}} \times 100 \%
$$

Keterangan :

$$
\begin{aligned}
& \mathrm{BA}=\text { Berat awal } \\
& \mathrm{Ba}=\text { Berat akhir }
\end{aligned}
$$

\section{c. Viskositas (Kadar Kekentalan)}

Sampel dimasukkan kedalam gelas piala 500 ml. Kemudian diukur viskositasnya dengan viskometer brookfield (LVT) pada kecepatan $30 \mathrm{rpm}$, ukuran spindel disesuaikan dengan kekentalan sampel. Nilai viskositas diperoleh dari hasil pengkalian skala yang terbaca dengan faktor perlakuan (Peleg dan Bagley (1983) dalam Andarwulan et al. (2011)).

\section{d. Uji Organoleprtik}

Uji organoleptik dengan menggunakan metode hedonik yaitu uji tingkat kesukaan terhadap tekstur, rasa, warna dan aroma dari susu jagung (Soekarto, 1985). Contoh yang sudah diberi kode disajikan secara acak kepada panelis, kemudian panelis diminta memberikan penilaian dengan memilih salah satu kriteria yaitu 1 = Sangat tidak suka, $2=$ Tidak suka, $3=$ Agak suka, $4=$ Suka, 5 = Sangat suka

\section{Pengolahan Data}

Penelitian ini menggunakan Rancangan Acak lengkap (RAL), yang terdiri dari 4 perlakuan dan masing-masing 3 kali ulangan sesuai metode yang dikemukakan Sudarmadji dkk (1989).rumusnya sebagai berikut :

$$
\mathrm{Yij}=\mu+\alpha_{\mathrm{i}}+\Sigma_{\mathrm{i}} \square
$$

Dimana :

Yij = Pengamatan pada perlakuan substitusi pada jagung manis dengan jagung hibridake-i dan ulangan ke-j

$\mu=$ Nilai rataan umum pengamatan

$\alpha_{\mathrm{i}} \quad=$ Pengaruh faktor substitusi jagung manis dengan jagung hibrida ke-i

$\mathrm{i}=1,2, \ldots \ldots, \mathrm{t}$ dan $\mathrm{j}=1,2, \ldots \ldots, \mathrm{r}$

$\Sigma_{\mathrm{i}} \square=$ Pengaruh galat perlakuan substitusi jagung manis dengan jagung hibrida ke-i, dan ulangan ke-j

\section{HASIL DAN PEMBAHASAN Kadar Air Susu Jagung}

Air merupakan komponen penting dalam bahan makanan karena air dapat mempengaruhi penampakan, tekstur, serta cita rasa makanan. Kandungan air dalam 
bahan makanan menentukkan acceptability, kesegaran, dan daya tahan bahan tersebut (Winarno, 2008). Pengujian kadar air dimaksudkan untuk mengetahui total air yang terkandung

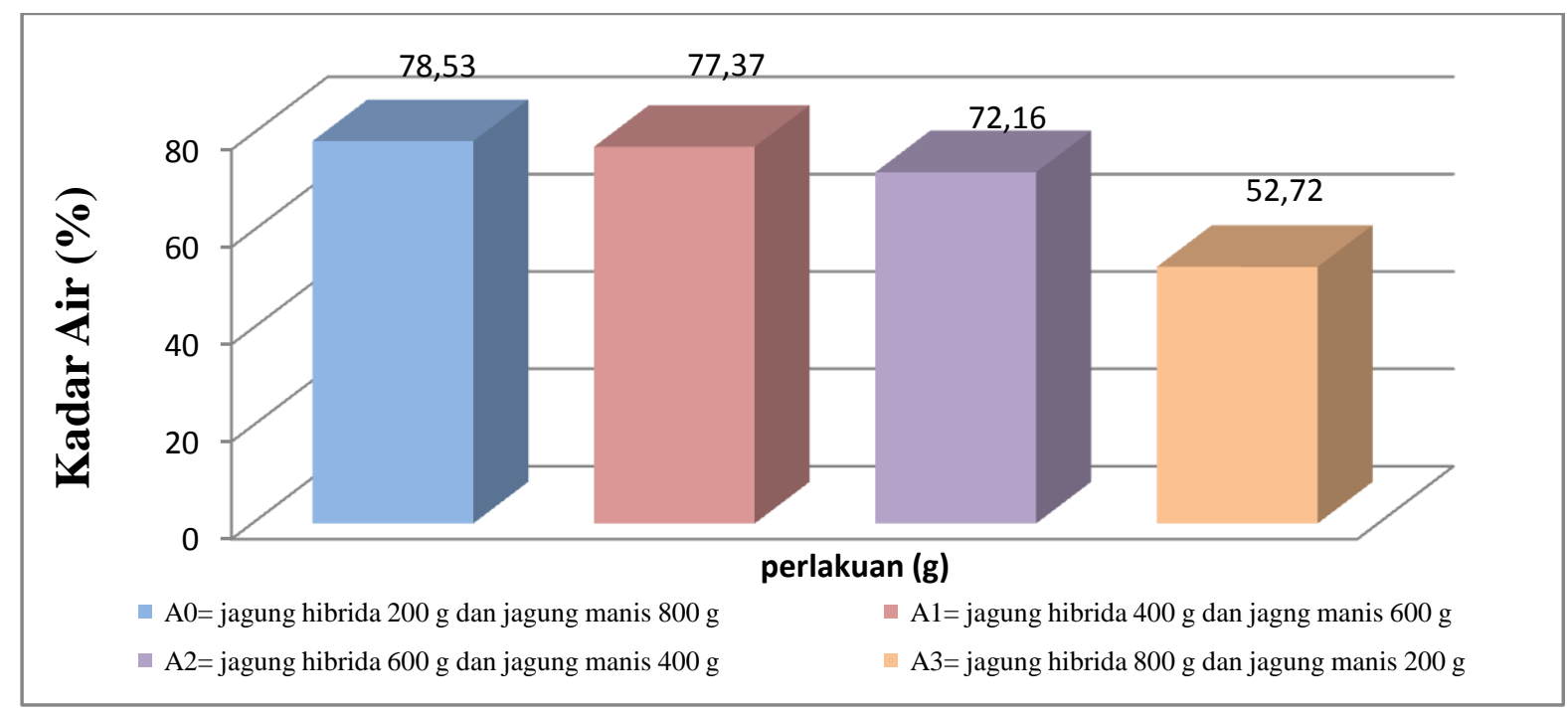

Gambar 1. Hasil Uji Kandungan kadar air pada susujagung

Gambar 1 menunjukan bahwa kadar air susu pada perlakuan A0 (jagung hibrida $200 \mathrm{~g}$ dan jagung manis $800 \mathrm{~g}$ ) yaitu 78,53\%, perlakuan A1 (jagung hibrida $400 \mathrm{~g}$ dan jagung manis $600 \mathrm{~g}$ ) yaitu $77,37 \%$, perlakuan A2 (jagung hibrida $600 \mathrm{~g}$ dan jagung manis $400 \mathrm{~g}$ ) yaitu 72,16\%, dan A3 (jagung hibrida 800 g dan jagung manis 200 g) yaitu $52,72 \%$.

Kadar air tertinggi susu jagung dari formulasi jagung hibrida dan jagung manis sebesar $78,53 \%$ diperoleh dari perlakuan A0 (jagung hibrida $200 \mathrm{~g}$ dan jagung manis $800 \mathrm{~g}$ ) dan terendah sebesar $52,72 \%$ diperoleh pada perlakuan A3 (jagung hibrida $800 \mathrm{~g}$ dan jagung manis $200 \mathrm{~g}$ ). Semakin tinggi formulasi jagung dalam susu jagung dengan formulasi jagung hibrida dan jagung manis. Hasil pengamatan uji kadar air pada produk susu jagung dapat dilihat pada Gambar 1. 
dihasilkan tidak memenuhi standar kadar air secara umum.

Berdasarkan analisis sidik ragam menunjukkan bahwa formulasi jagung hibrida dan jagung manis berpengaruh sangat nyata terhadap kadar air susu jagung dan dilanjutkan dengan Uji lanjut BNJ (0,01). Menurut Astawan (2014), bahwa kandungan air dalam bahan makanan mempengaruhi daya tahan bahan makanan terhadap serangan mikroba. Semakin tinggi kandungan airnya, maka semakin besar kemungkinan makanan tersebut cepat rusak, dimana kandungan air yang tinggi dapat dimanfaatkan oleh mikroorganisme khususnya kapang untuk tumbuh dan berkembang biak sehingga dapat membahayakan kesehatan tubuh akibat keracunan. Penyimpanan menggunakan suhu rendah pada bahan makanan dapat menyebabkan terhambatnya pertumbuhan mikroorganisme pembusuk.

\section{Kadar Gula}

Gula merupakan senyawa organik yang penting sebagai bahan makanan, karena gula dicerna dan di dalam tubuh sebagai sumber kalori. Disamping sebagai bahan makanan, gula digunakan pula sebagai pengawet makanan, bahan baku, alkohol dan pencampur obat-obatan. Gula merupakan senyawa kimia yang termasuk karbohidrat, memiliki rasa manis dan larut dalam air. Gula disamping sebagai bahan pemberi rasa, juga dengan penambahan gula berpengaruh pada kekentalan gel, sebab gula akan mengikat air, akibatnya pengembangan pati menjadi lambat. Suhu gelatinisasi menjadi lebih tinggi, menyebabkan gel lebih tahan dan awet (Sudarmadji, 1997).

Sukrosa adalah jenis gula yang paling dominan dibandingkan fruktosa dan glukosa pada jagung (Muchtadi, 1988 dalam Satiarini, 2006).Jagung manis banyak mengandung gula bebas dan pati, yang merupakan polimer dari gula tersebut, kandungan gula pada jagung manis bukan merupakan glukosa atau sukrosa, namun dalam bentuk fruktosa, sejenis polimer gula yang dikenal dengan gula buah. Fruktosa merupakan gula kompleks yang tidak langsung dicerna oleh alat pencernaan manusia, tetapi harus diolah terlebih dahulu menjadi gula sederhana. Sebelum fruktosa tercerna, biasanya sudah terbuang bersama urin, sehingga tidak sempat terserap(Wahyudi, 2005). Pengujian kadar gula dimaksudkan untuk mengetahui total gula yang terkandung dalam susu jagung yang dihasilkan dengan formulasi jagung hibrida dan jagung manis. Hasil pengamatan uji kadar gula pada produk susu jagung dapat dilihat pada Gambar 2. 


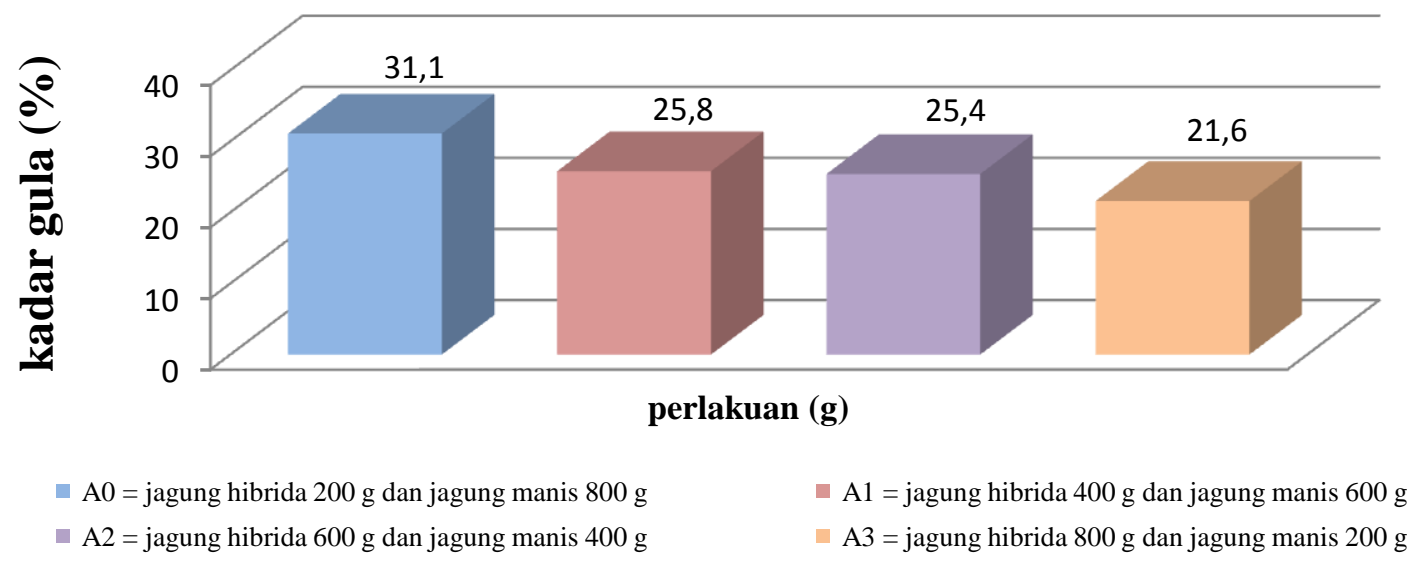

Gambar 2. Hasil Uji Kandungan kadar gula pada susujagung

Gambar 2 menunjukan bahwa kadar gula susu pada perlakuan A0 (jagung hibrida 200 grdan jagung manis 800 gr) yaitu $31,1 \%$, perlakuan A1 (jagung hibrida 400 gr dan jagung manis 600 gr) yaitu 25,8\%, perlakuan A2 (jagung hibrida 600 gr dan jagung manis 400 gr) yaitu 25,4\%, dan A3 (jagung hibrida 800 gr dan jagung manis $200 \mathrm{gr}$ ) yaitu $21,6 \%$.

Kadar gula susu jagung dari formulasi jagung hibrida dan jagung manis berkisar antara $21,6 \%$ sampai $31,1 \%$. Kadar gula tertinggi susu jagung sebesar $31,1 \%$ diperoleh dari perlakuan A0 dengan formulasi jagung hibrida $200 \mathrm{~g}$ dan jagung manis $800 \mathrm{~g}$, dan kadar gula terendah diperoleh dari perlakuan A3 dengan formulasi jagung hibrida $800 \mathrm{~g}$ dan jagung manis 200 g. Semakin banyak formulasi jagung manis maka kadar gula dalam produk susu jagung yang dihasilkan semakin tinggi. Hal ini disebabkan kandungan kadar gula pada jagung manis lebih besar dari kandungan kadar gula pada jagung hibrida. Hal ini sesuai dengan pendapat Palunkun (1995), bahwa jagung manis sesuai dengan namanya memiliki kadar gula yang cukup tinggi sehingga rasanya lebih manis dari jagung hibrida.

Berdasarkan analisis sidik ragam menunjukkan bahwa formulasi jagung hibrida dan jagung manis berpengaruh sangat nyata terhadap kadar gula susu jagung sehingga dilanjutkan dengan Uji lanjut BNJ $(0,01)$.

\section{Viskositas}

Viskositas atau kekentalan merupakan ukuran yang menyatakan besarnya hambatan yang terdapat dalam larutan. Hambatan ini berasal dari gerakan acak dari molekul zat cair tersebut atau berasal dari faktor-faktor yang terkandung didalam larutan tersebut. Viskositas berpengaruh terhadap bentuk dan penerimaan rasa dari produk olahan yang berupa cairan. Dalam sistem SI, viskositas dinyatakan dalam Pa.s (pascal-second), sedangkan dalam sistem cgs dinyatakan 
dalam centipoises/cP $(\mathrm{cP}=0,01 \mathrm{P})$. Nilai viskositas dapat digunakan sebagai parameter kerusakakn produk minuman (Winarno, 1997). Pengukuran viskositas dilakukan dengan alat viskometer brookfield. Nilai viskositas dapat digunakan sebagai parameter kerusakan produk minuman susu jagung. Hasil pengamatan ujiviskositas (kadar kekentalan) pada produk susu jagung dapat dilihat pada Gambar 3.

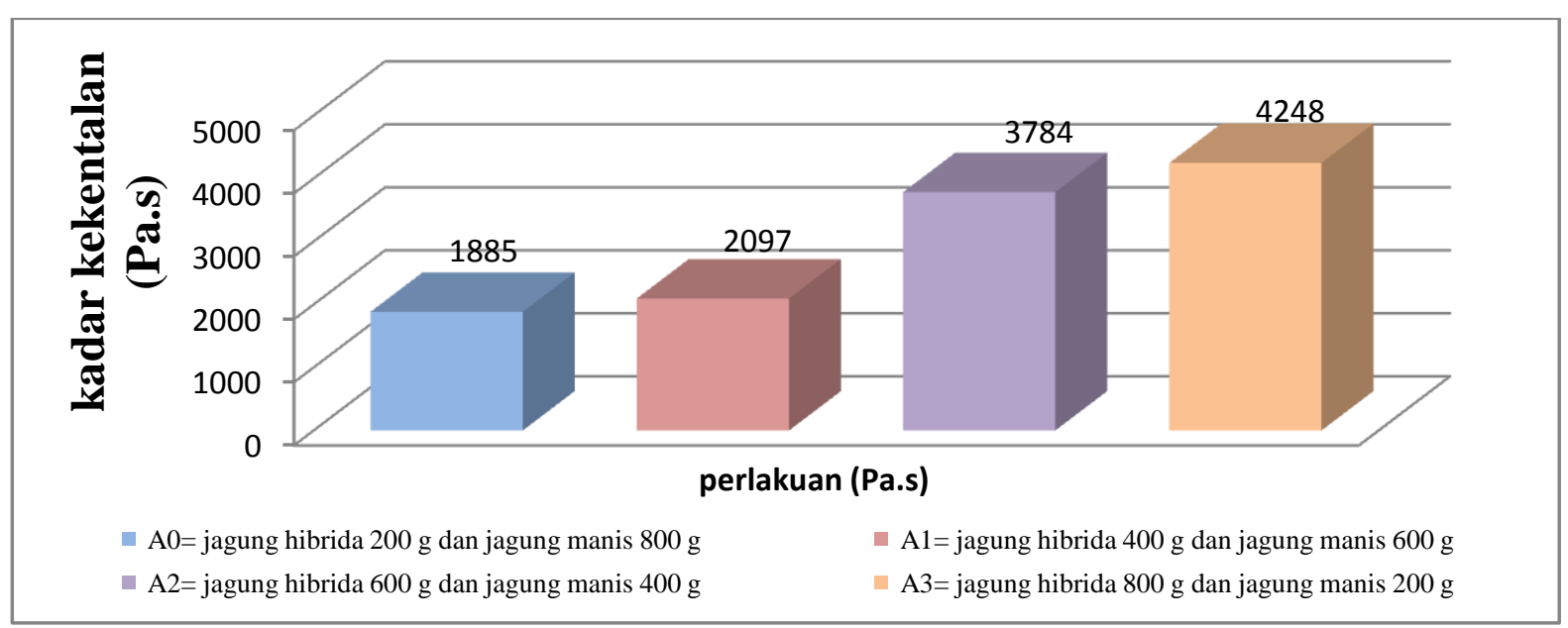

Gambar 3. Hasil Uji Viskositas susujagung

Gambar 3 menunjukan bahwa kadar kekentalan susu pada perlakuan A0 (jagung hibrida 200 grdan jagung manis 800 gr) yaitu 1885 Pa.s, perlakuan A1 (jagung hibrida 400 gr dan jagung manis 600 gr) yaitu 2097 Pa.s, perlakuan A2 (jagung hibrida 600 gr dan jagung manis 400 gr) yaitu 3784 Pa.s, dan A3 (jagung hibrida 800 gr dan jagung manis 200 gr) yaitu $4248 \mathrm{~Pa} . \mathrm{s}$.

Viskositas susu jagung dari formulasi jagung hibrida dan jagung manis berkisar antara 1885 Pa.s - 4248 Pa.s. Viskositas tertinggi susu jagung sebesar 4248 Pa.s diperoleh dari perlakuan A3 (jagung hibrida $800 \mathrm{~g}$ dan jagung manis 200 g). Semakin banyak formulasi jagung hibrida maka vsikositas dalam produk susu jagung yang dihasilkan semakin tinggi. Hal ini sesuai dengan pendapat Suarni dan Widowati (2002), bahwa jumlah pati yang terkandung dalam jagung hibrida cukup tinggi jika dibandingkan dengan jagung manis yaitu $70 \%$, sedangkan pada jagung manis hanya 22,8\%. Pati sangat mempengaruhi viskositas susu jagung karena pati dapat mengalami gelatinisasi bila mendapatkan perlakuan panas yang cukup (Winarno, 1997).

Viskositas terendah diperoleh dari perlakuan A0 (jagung hibrida $200 \mathrm{~g}$ dan jagung manis $800 \mathrm{~g}$ ). Semakin banyak formulasi jagung manis maka vsikositas dalam produk susu jagung yang dihasilkan semakin rendah. Hal ini disebabkan pada jagung manis secara alamiah telah banyak 
mengandung gula sehingga dapat membantu menurunkan viskositas susu jagung. Selain itu jagung manis tidak dapat membentuk pati karena terdapat gen resesif yang dapat menghambat pembentukan pati sehingga jumlah gula dalam jagung dua kali lebih banyak dibanding jagung hibrida (Aak, 1995). Sehingga perlakuan penambahan jagung manis yang lebih banyak menghasilkan susu jagung dengan vsikositas yang lebih rendah.

Berdasarkan analisis sidik ragam menunjukkan bahwa formulasi jagung hibrida dan jagung manis berpengaruh sangat nyata terhadap viskositas susu jagung sehingga dilanjutkan dengan Uji lanjut $\mathrm{BNJ}(0,01)$.

\section{Organoleptik}

\section{a. Rasa}

Rasa dapat dinilai dengan adanya tanggapan rangsangan kimiawi oleh indera pencicip (lidah). Agar suatu senyawa dapat dikenali rasanya, senyawa tersebut harus dapat larut dalam air liur sehingga dapat mengadakan hubungan dengan mikrovilus dan impuls yang terbentuk dikirim melalui syaraf ke pusat susunan syaraf. Manis dan asin paling banyak dideteksi oleh kuncup pada ujung lidah, kuncup pada sisi lidah paling peka asam, sedangkan kuncup bagian pangkal lidah peka terhadap pahit (Winarno, 1997).

Tingkat rasa produk susu yang dihasilkan dipengaruhi oleh penggunaan formulasi jagung hibrida dan jagung manis serta bahan tambahan, seperti gula dan garam dalam komposisi susu serta proses pencampuran dan pemasakan. Untuk mengetahui nilai rasa susu yang dihasilkan, perhitungan tingkat rasa produk susu dapat dinilai dengan metode hedonik. Hasil penilaian uji hedonik terhadap susu jagung dapat dilihat pada Gambar 4.

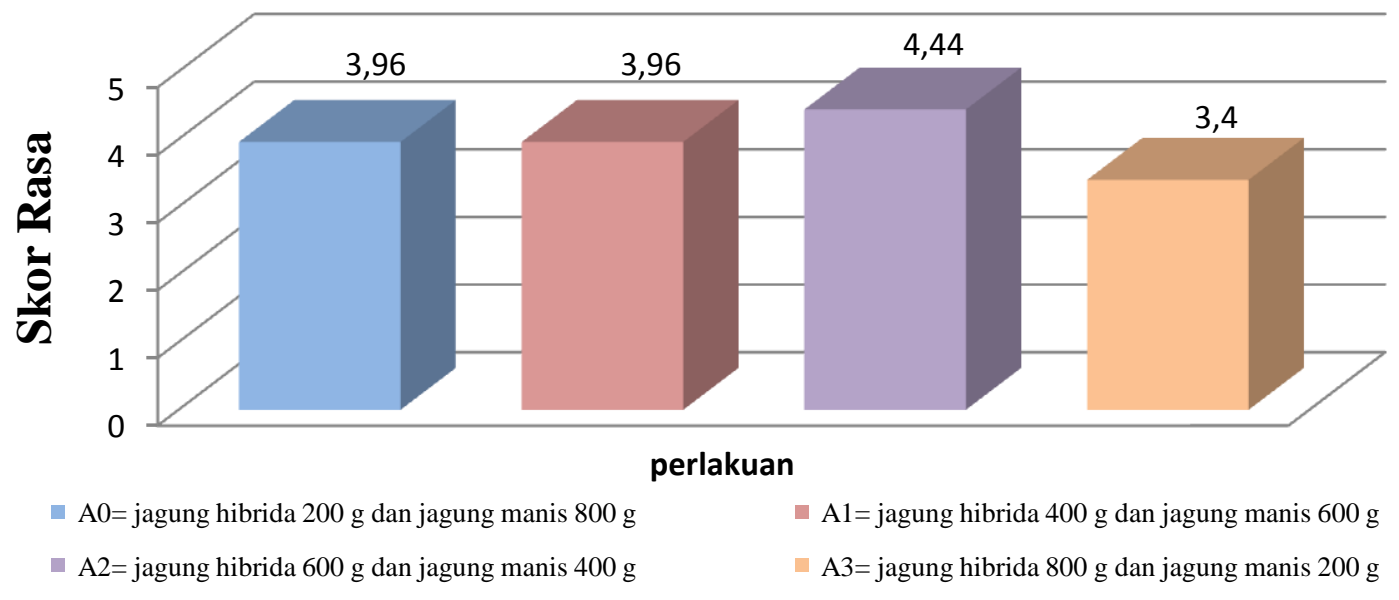

Gambar 4. Hasil Uji Organoleptik Terhadap Rasa Pada Susu Jagung 
Hasil uji organoleptik terhadap rasa susu yang dihasilkan menunjukkan bahwa rasa produk susu yang paling disukai oleh panelis yaitu pada perlakuan A2 (jagung hibrida $600 \mathrm{~g}$ dan jagung manis $400 \mathrm{~g}$ ) dengan skor 4,44 (suka), dan yang paling tidak disukai oleh panelis yaitu rasa susu pada perlakuan A3 (jagung hibrida $800 \mathrm{~g}$ dan jagung manis $200 \mathrm{~g}$ ). Sedangkan pada perlakuan A0 (jagung hibrida $200 \mathrm{~g}$ dan jagung manis $800 \mathrm{~g}$ ) memiliki skor 3,96 (agak suka) dan perlakuan A1 (jagung hibrida $400 \mathrm{~g}$ dan jagung manis $600 \mathrm{~g}$ ) memiliki skor 3,96 (agak suka).

Hasil uji organoleptik terhadap rasa bertujuan untuk mengetahui tingkat respon dari panelis mengenai kesukaannya terhadap susu yang dihasilkan pada masing-masing perlakuan. Hasil penilaian panelis pada Gambar 4 menunjukkan bahwa susu yang diperoleh dari 4 perlakuan memberikan rasa agak suka sampai suka.

$$
\text { Susu yang dihasilkan }
$$
menunjukkan tingkat kesukaan terhadap rasa ang berbeda-beda. Hal ini dipengaruhi adanya perbedaan perlakuan dari masing-masing susu yang dihasilkan, yaitu adanya perbandingan antara jagung hibrida dan jagung manis. Perlakuan yang paling disukai oleh panelis terhadap rasa susu yang dihasilkan adalah perlakuan A2 (jagung hibrida $600 \mathrm{~g}$ dan jagung manis
400 g), hal ini disebabkan karena pada perlakuan A2 memiliki cita rasa yang lebih enak dan rasa khas susu sangat dominan dengan rasa jagung.

\section{b. Aroma}

Aroma adalah bau yang ditimbulkan oleh rangsangan kimia yang tercium oleh syaraf-syaraf olfaktori yang berada dalam rongga hidung ketika makanan masuk kedalam mulut (Winarno, 2008). Aroma menentukan kelejatan bahan makanan cita rasa dari bahan pangan sesungguhnya terdiri dari tiga komponen, yaitu bau, rasa, dan rangsangan mulut. Bau yang dihasilkan dari makanan banyak menentukan kelezatan bahan pangan tersebut. Dalam hal bau lebih banyak sangkut pautnya dengat alat indera penciuman (Sudarmadji, dkk. 1997).

Hasil uji organoleptik terhadap aroma bertujuan untuk mengetahui tingkat respon dari panelis mengenai kesukaan terhadapnya terhadap formulasi jagung hibrida dan jagung manis pada masingmasing perlakuan. Hasil uji organoleptik terhadap aroma pada Gambar 5 menunjukkan bahwa susu yang diperoleh dari 4 perlakuan memberikan aroma agak suka. Hasil nilai rata-rata penilaian dari 25 panelis dengan menggunakan metode hedonik melalui pengujian organoleptik, panelis memberikan nilai skor terhadap aroma susu yaitu 3,68-3,88 (agak suka). 


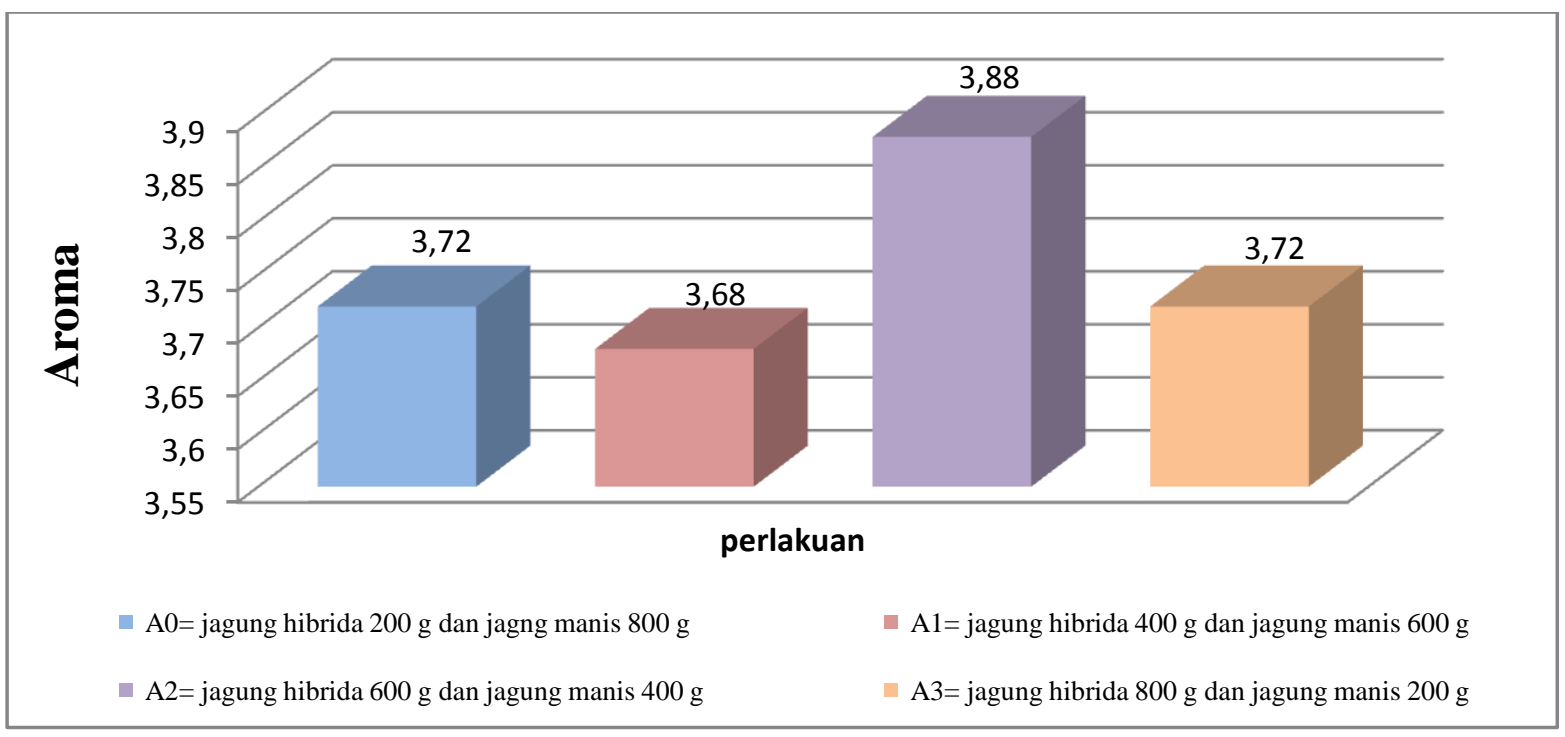

Gambar 5. Hasil uji organoleptik terhadap aroma susu jagung

Hasil uji organoleptik menunjukkan aroma yang paling disukai oleh panelis adalah susu yang diperoleh dari perlakuan A2 (jagung hibrida $600 \mathrm{~g}$ dan jagung manis $400 \mathrm{~g}$ ) dengan skor 3,88 (agak suka) dan yang paling tidak disukai oleh panelis adalah susu yang diperoleh dari perlakuan A1 (jagung hibrida $400 \mathrm{~g}$ dan jagung manis 600 gr). Aroma susu pada perlakuan A0 (jagung hibrida $200 \mathrm{~g}$ dan jagung manis $800 \mathrm{~g}$ ) dan perlakuan A3 ( jagung hibrida $800 \mathrm{~g}$ dan jagung manis 200 g) memiliki skor yang sama yaitu 3,72 dalam taraf agak disukai oleh panelis.

Aroma susu yang dihasilkan pada perlakuan A2 (Jagung hibrida $600 \mathrm{~g}$ dan jagung manis $400 \mathrm{~g}$ ) adalah aroma yang harum dan khas sesuai dengan bahan baku yang digunakan dalam pembuatan susu, yaitu jagung hibrida dan jagung manis. Aroma yang harum dan khas dari jagung hibrida berasal dari kandungan pati yang terdegradasi. Menurut Soewarno (1985), pembentukan aroma dan flavor disebabkan oleh kandungan karbohidrat yang terdegradasi pada jagung hibrida.

Pada umumnya bau yang diterima oleh hidung dan otak lebih banyak merupakan berbagai ramuan atau campuran empat bau utama yaitu harum, asam, tengik, dan hangus. Bau makanan banyak menentukan kelezatan bahan makanan tersebut. Suatu zat harus bersifat mudah menguap dan larut dalam air sehingga dapat menghasilkan bau yang baik dalam penilaian aroma (Winarno, 1997).

\section{c. Warna}

Warna merupakan karakteristik yang menentukan penerimaan atau penolakan suatu produk toleh konsumen. Kesan pertama yang didapat dari bahan pangan adalah warna. Suatu bahan pangan 
meskipun dinilai enak dan teksturnya sangat baik, tetapi memiliki warna yang kurang sedap dipandang atau memberi kesan telah menyimpang dari warna yang seharusnya, maka seharusnya tidak dikonsumsi. Penilaian mutu bahan makana yang umumnya sangat tergantung pada beberapa faktor antara lain cita rasa, warna, tekstur dan nilai gizinya. Tetapi sebelum faktor-faktor tersebut dipertimbangkan secara visual warna kadang-kadang sangat menentukan (Winarno, 2008).
Warna produk pangan adalah salah satu sifat organoleptik yang terdapat pada produk pangan. Faktor-faktor yang mempengaruhi warna dari produk susu adalah pengunaan gula dan formulasi jagung hibrida dan jagung manis. Warna dapat memberikan penilaian yang berbeda terhadap pemakaian formulasi jagung hibrida dan jagung manis. Untuk mengetahui nilai warna dari susu yang dihasilkan, perhitungan tingkat warna produk susu dapat dinilai dengan uji hedonik. Hasil uji hedonik susu jagung dapat dilihat pada Gambar 6.

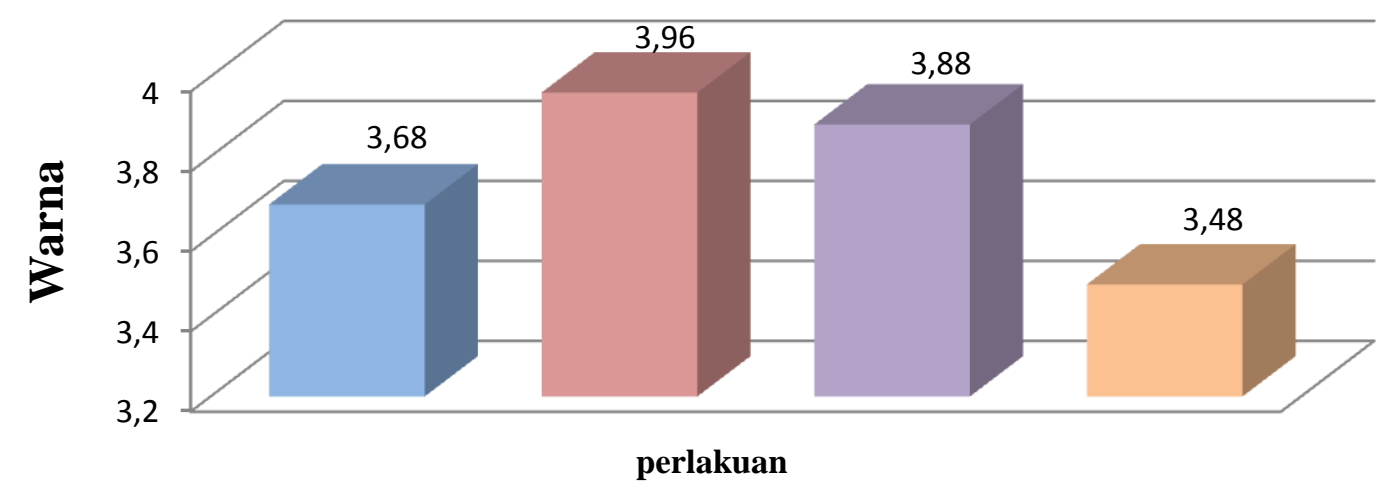

- $\mathrm{A} 0=$ jagung hibrida $200 \mathrm{~g}$ dan jagung manis $800 \mathrm{~g}$

- $\mathrm{A} 1=$ jagung hibrida $400 \mathrm{~g}$ dan jagung manis $600 \mathrm{~g}$

- A2= jagung hibrida $600 \mathrm{~g}$ dan jagung manis $400 \mathrm{~g}$

A3 $=$ jagung hibrida $800 \mathrm{~g}$ dan jagung manis $200 \mathrm{~g}$

Gambar 6. Hasil Uji Organoleptik Terhadap Warna Susu Jagung

Hasil uji organoleptik terhadap warna yang dihasilkan menunjukkan bahwa warna produk susu yang disukai oleh panelis yaitu pada perlakuan A1 ( jagung hibrida $600 \mathrm{~g}$ dan jagung manis 200 g) dengan skor 3,96 (agak suka), yang paling tidak disukai oleh panelis adalah warna susu pada perlakuan A3 ( jagung hibrida $800 \mathrm{~g}$ dan jagung manis $200 \mathrm{~g}$ ).
Sedangkan warna susu pada perlakuan A0 ( jagung hibrida $200 \mathrm{~g}$ dan jagung manis 800 g) dengan skor 3,68 (agak suka) dan perlakuan A2 ( jagung hibrida $600 \mathrm{~g}$ dan jagung manis $400 \mathrm{~g}$ ) memiliki skor 3,88 (agak suka). Skor yang berbeda tersebut disebabkan oleh formulasi jagung hibrida dan jagung manis. Jagung hibrida dan jagung manis memberikan kontribusi 
warna terhadap produk susu yang dihasilkan. Formulasi jagung hibrida dan jagung manis yang digunakan memberikan pengaruh terhadap warna yang dihasilkan pada produk tersebut.

Warna keseluruhan susu yang hampir tidak berbeda satu sama lainnya mengakibatkan panelis tidak mampu membedakan warna susu dari setiap perlakuan. Inilah yang menyebabkan ketidakteraturan nilai skor warna susu yang diperoleh. Warna susu yang dihasilkan pada perlakuan A2 (jagung hibrida $400 \mathrm{~g}$ dan jagung manis $600 \mathrm{~g}$ ) lebih disukai, sedangkan warna yang dihasilkan pada perlakuan A3 (jagung hibrida $800 \mathrm{~g}$ dan jagung manis $200 \mathrm{~g}$ ) kurang disukai karena memiliki warna kuning pucat dan terlihat kurang menarik dari perlakuan lainnya. Formulasi jagung hirida dan jagung manis yang hampir seimbang menimbulkan warna yang disukai oleh panelis, karena jagung hibrida yang digunakan memiliki warna kuning terang dibandingakan jagung manis.

\section{Kekentalan}

Penampilan suatu produk sangat dipengaruhi oleh keadaan fisik dari produk tersebut. Kekentalanmerupakan unsur tekstur sifat organoleptik yang dinilai panelis pada suatu produk pangan melalui beberapa cara, yaitu diraba oleh jari atau alat bantu peraba, diamati oleh mata dan dirasakan dalam rongga mulut(Soewarno, 1985).Karakteristik yang diamati dari tekstur susu jagung yaitu cair hingga kental. kekentalan merupakan sifat fisik yang harus diperhatikan dalam penentuan kualitas susu yang dihasilkan. Hasil uji organoleptik terhadap kekentalan pasda susu jagung dapat dilihat pada Gambar 7.

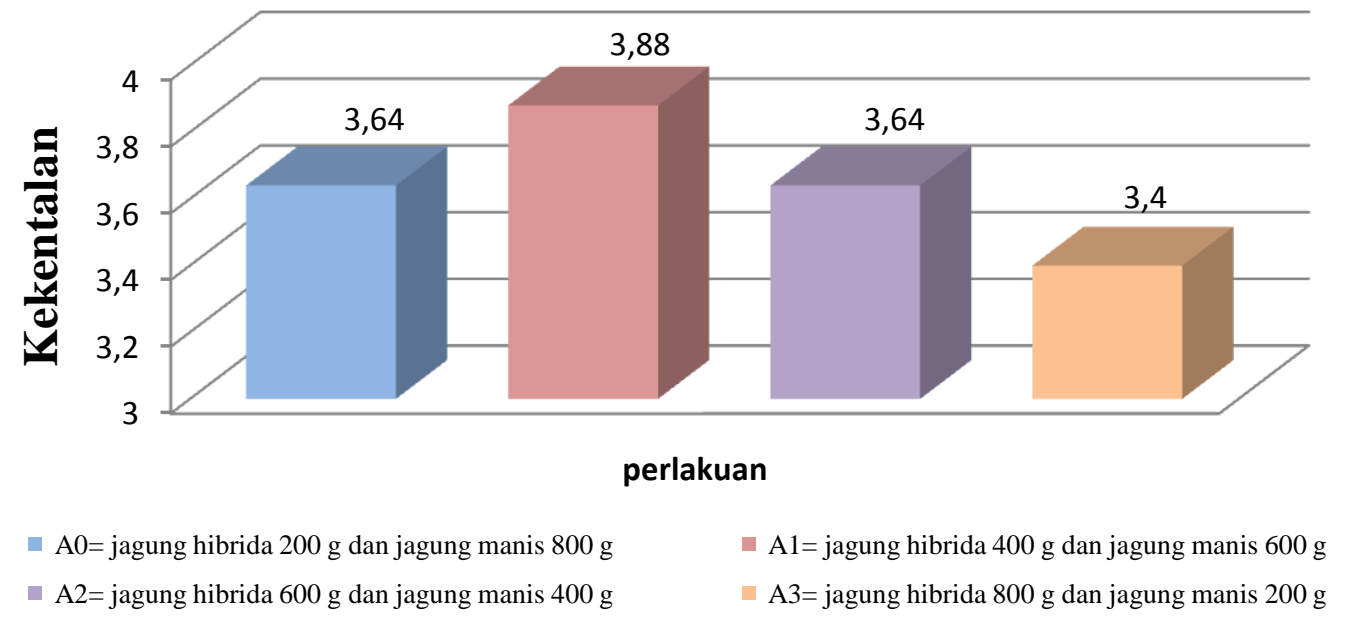

Gambar 7. Hasil Uji Organoleptik Terhadap Kekentalan Pada Susu Jagung. 
Hasil uji organoleptik terhadap kekentalan yang dihasilkan bahwa kekentalan produk susu yang disukai oleh panelis yaitu pada perlakuan A1 (jagung hibrida $400 \mathrm{~g}$ dan jagung manis $600 \mathrm{~g}$ ) dengan skor 3,88 (agak suka), yang paling tidak disukai oleh oleh panelis adalh kekentalan susu pada perlakuan A3 (jagung hibrida $800 \mathrm{~g}$ dan jagung manis 200 g) dengan skor 3,4 (agak suka). Sedangkan kekentalan susu pada perlakuan A0 (jagung hibrida $200 \mathrm{~g}$ dan jagung manis $800 \mathrm{~g}$ ) dan pada perlakuan A2 (jagung hibrida $600 \mathrm{~g}$ dan jagung manis $400 \mathrm{~g}$ ) memiliki skor yang sama yaitu 3,64 (agak suka). Panelis memberikan skor yang tidak banyak perbedaan terhadap kekentalan susu yang dihasilkan disebabkan oleh penggunaan formulasi jagung hibrida dan jagung manis yang tidak terlalu ada perbedaan terhadap kekentalan setiap perlakuan.

Semakin tinggi formulasi jagung manis yang ditambahkan maka produk susu yang dihasilkan semakin encer atau tidak kental. Hal ini disebabkan kandungan pati pada jagung manis lebih rendah dibanding kandungan pati pada jagung hibrida. Sehingga penggunaan formulasi jagung manis yang lebih tinggi pada produk susu menghasilkan susu yang encer atau tidak kental.

\section{KESIMPULAN DAN}

Kesimpulan yang diperoleh berdasarkan penelitian yang telah dilakukan adalah sebagai berikut :

1. Formulasi jagung hibrida dan jagung manis dalam pembuatan susu memberikan pengaruh sangat nyata terhadap kadar air, kadar gula dan viskositas susu jagung yang dihasilkan. Kadar air dan kadar gula tertinggi pada produk susu jagung terletak pada perlakuan A0 (jagung hibrida $200 \mathrm{~g}$ dan jagung manis 800 g), dan terendah pada perlakuan A3 (jagung hibrida $800 \mathrm{~g}$ dan jagung manis 200 g). Sedangkan viskositas tertinggi terletak pada perlakuan A3 (jagung hibrida $800 \mathrm{~g}$ dan jagung manis $200 \mathrm{~g}$ ) dan terendah pada perlakuan A0 (jagung hibrida $200 \mathrm{~g}$ dan jagung manis $800 \mathrm{~g}$ )

2. Tingkat kesukaan panelis terhadap warna dan kekentalan dengan kategori agak suka terletak pada perlakuan A1 (jagung hibrida $400 \mathrm{~g}$ dan jagung manis $600 \mathrm{~g}$ ), sedangkan tingkat kesukaan terhadap rasa dan aroma terletak pada perlakuan A2 (jagung hibrida $600 \mathrm{~g}$ dan jagung manis 400 g).

\section{DAFTAR PUSTAKA}

Aak. 1993. Teknik Bercocok Tanam Jagung. Kanisius. Yogyakarta. 
Andarwulan N, Kusnandar F, Herawati D. 2011. Analisis pangan. Jakarta (ID): Dian Rakyat.

Astawan, M,. S. Koswara dan F. Herdiani. 2014. Pemanfaatan Rumput Laut (Eucheuma cotonii) untuk Meningkatkan Kadar Iodium dan Serat Pangan Fruit leather dan Dodol. Jurnal Teknologi dan Industri Pangan.

Dinas Pertanian dan Ketahanan Pangan, 2014. Produksi Tanaman Jagung. Pohuwato.

Iskandar, D. 2008. Morfologi Tanaman dan Fase Pertumbuhan Jagung Manis dan jagung hibrida. Jurnal Sains dan Teknologi IPTEK. Universitas Sumatera Utara.

Palungkun R, Tim Penulis PS. 1995. Sweet Corn Baby Corn. PT. Penebar Swadaya. Depok.

Satiarini, B. (2006). Kajian Produksi dan Profitabilitas Pembuatan Susu Jagung. Institut Pertanian Bogor. Bogor. Skripsi.

Siregar, G.S. 2009. Analisis Respon Penawaran Komoditas Jagung dalam RangkaMencapai Swasembada Jagung di Indonesia. Skripsi S-1 Fakultas Ekonomi dan Manajemen Institut Pertanian Bogor.

Soekarto, S.T. 1985. Penilaian Organoleptik.Bharata Karya Aksara. Jakarta.
Soewarno TS. 1985. Penilaian Organoleptik Untuk Industri Pangan dan Hasil Pertanian. Bharatara Karya Aksara. Jakarta

Suarni dan S. Widowati. (2002). Struktur, Komposisi, dan Nutrisi Jagung. http://balitsereal.litbang.depta n.go.id/ind/images/stories/tiga nol.pdf. Diakses pada 28 Oktober 2016

Sudarmadji, S., B. Haryono, dan Suhardi, 1989. Prosedur Analisa Untuk Bahan Utama, Jakarta.

Supriyanto, 2006. Teknologi Pengolahan Jagung. Makalah Seminar. Jakarta.

http://www.pengolahan susu jagung.com.Diakses pada 27 Oktober 2016

Syamsir. 2008. Pembuatan susu jagung.

Departemen Ilmu dan

Tekhnologi Pangan.

Wahyudi,Johan. 2005. JagungManisBoleh untuk

Diabetes.http://www.iptek.net.i d.Diakses pada 29 Oktober 2016

Winarno, F.G. 1997. Kimia Pangan danGizi. Gramedia Pustaka Utama.Jakarta.

Winarno, F.G., 2008.Kimia Pangan danGizi. Gramedia Pustaka Utama.Jakarta. 